\title{
Debris-flow activity in abandoned channels of the Manival torrent reconstructed with LiDAR and tree-ring data
}

\author{
J. Lopez Saez ${ }^{1}$, C. Corona $^{1}$, M. Stoffe ${ }^{2,3}$, A. Gotteland ${ }^{1}$, F. Berger ${ }^{1}$, and F. Liébault ${ }^{4}$ \\ ${ }^{1}$ Cemagref UR EMGR, 2 rues de la papeterie, BP 76, 38402 Saint-Martin d'Hères Cedex, France \\ ${ }^{2}$ Laboratory of Dendrogeomorphology, Institute of Geological Sciences, University of Bern, Baltzerstr. 1+3, \\ 3012 Bern, Switzerland \\ ${ }^{3}$ Climatic Change and Climate Impacts, Institute for Environmental Sciences, University of Geneva, 7, chemin de Drize, 1227 \\ Carouge-Geneva, Switzerland \\ ${ }^{4}$ Cemagref UR ETGR, 2 rues de la papeterie, BP 76, 38402 Saint-Martin d'Hères Cedex, France
}

Received: 31 January 2011 - Accepted: 14 March 2011 - Published: 9 May 2011

\begin{abstract}
Hydrogeomorphic processes are a major threat in many parts of the Alps, where they periodically damage infrastructure, disrupt transportation corridors or even cause loss of life. Nonetheless, past torrential activity and the analysis of areas affected during particular events remain often imprecise. It was therefore the purpose of this study to reconstruct spatio-temporal patterns of past debris-flow activity in abandoned channels on the forested cone of the Manival torrent (Massif de la Chartreuse, French Prealps). A Light Detecting and Ranging (LiDAR) generated Digital Elevation Model (DEM) was used to identify five abandoned channels and related depositional forms (lobes, lateral levees) in the proximal alluvial fan of the torrent. A total of 156 Scots pine trees (Pinus sylvestris L.) with clear signs of debris flow events was analyzed and growth disturbances (GD) assessed, such as callus tissue, the onset of compression wood or abrupt growth suppression. In total, $375 \mathrm{GD}$ were identified in the tree-ring samples, pointing to 13 debris-flow events for the period 1931-2008. While debris flows appear to be very common at Manival, they have only rarely propagated outside the main channel over the past 80 years. Furthermore, analysis of the spatial distribution of disturbed trees contributed to the identification of four patterns of debris-flow routing and led to the determination of three preferential breakout locations. Finally, the results of this study demonstrate that the temporal distribution of debris flows did not exhibit significant variations since the beginning of the 20th century.
\end{abstract}

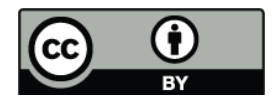

Correspondence to: J. Lopez Saez (jerome.lopez@cemagref.fr)

\section{Introduction}

Hydrogeomorphic processes represent one of the most common and widespread of all natural hazards in many mountain and hillslope environments worldwide (Jakob, 2005; Shroder et al., 2011). They repeatedly cause severe damage and destruction to settlement areas, transportation corridors, and infrastructure or even lead to loss of life, especially on alluvial fans and debris-flow cones. Because of their high flow velocity and poor temporal predictability, forecasting is rarely possible (Wieczorek and Snyder, 2009) and no rigorous(database) methods are available that would allow determination of event probability, be it based on physically measured characteristics of a catchment or on statistical approaches (Mayer et al., 2010). Therefore, in order to avoid damage or fatalities, an appropriate delineation of potentially hazardous areas is needed, demanding knowledge about event frequency and magnitude (Jakob and Bovis, 1996; Mayer et al., 2010).

A major obstacle for such analysis is the lack of data with satisfying spatial resolution or precision over medium to long timescales and on a continuing basis (Wieczorek and Snyder, 2009). Usually, the temporal distribution of hydrogeomorphic processes is estimated at supradecadal timescales and derived from large inventories of historical archives such as local, state government (e.g. administrative, fiscal or military works), religious (e.g. episcopal or diocesan archives), private or notarial archives (Barriendos et al., 2003). These archives include narrations, paintings, newspaper accounts, terrestrial or aerial photographs, remote sensing series, or incidental statements (Tropeano and Turconi, 2004; Coeur and Lang, 2008). However, difficulties are numerous in accessing, extracting, organizing, databasing, and analyzing

Published by Copernicus Publications on behalf of the European Geosciences Union. 
such information because it has not usually been collected for scientific purposes. Problems may involve conscientiousness of the observer, editing and recording process issues, and the haphazard nature of recorded events in both time and space (Ibsen and Brunsden, 1996). Furthermore, archival data is always biased toward catastrophic events and largely undersampled in unpopulated areas (Mayer et al., 2010). Additional anthropocentric bias is introduced when interviewing residents because human memory is short-lived, and highly selective (Barriendos et al., 2003), meaning such records will likely contain more frequent events of the recent past (Mayer et al., 2010).

Therefore, archival records should be supplemented with other techniques (Ibsen and Brunsden, 1996; Jakob, 2005). On forested cones, hydrogeomorphic processes can destroy or damage trees in or adjacent to their flow paths (Stoffel and Bollschweiler, 2008; Bollschweiler and Stoffel, 2010a). Dendrogeomorphology allows a reconstruction of past geomorphic activity to be inferred from information preserved in tree rings (Alestalo, 1971; Stoffel et al., 2005). In the past, dendrogeomorphic research has largely focused on the reconstruction of debris-flow frequency (e.g. Strunk, 1997; Bollschweiler and Stoffel, 2010b) and magnitude (e.g. Hupp, 1984; Stoffel, 2010). Spatial patterns of previous activity on cones and in channels have also repeatedly been compared with archival records on flooding (e.g. Stoffel et al., 2005; Mayer et al., 2010). In addition, triggering weather conditions or changes in the seasonality of debris-flow activity with time (Stoffel et al., 2008, 2011) were evaluated.

With a few exceptions, dendrogeomorphic studies focused on trees growing on cones; in contrast, trees growing inside or next to debris-flow channels have rarely been the subject of research, although they yield valuable data on (i) more recent or (ii) smaller in-channel events (e.g. Arbellay et al., 2010; Szymczak et al., 2010), as well as on (iii) periods of activity in currently abandoned channels (Bollschweiler et al., 2008).

It is therefore the aim of this study to reconstruct spatial patterns of past debris-flow activity inside and next to abandoned channels on the depositional cone of the Manival torrent (Massif de la Chartreuse, French Prealps). We used a Light Detecting and Ranging (LiDAR) generated Digital Elevation Model (DEM) to identify abandoned channels and related forms (lobes, lateral levees) in the proximal alluvial fan of the torrent and analyzed growth disturbances in 312 treering series obtained from 156 Scots pine (Pinus sylvestris $\mathrm{L}$.) trees disturbed by past debris flows. The paper (i) reports on the frequency of debris flows affecting abandoned channels, (ii) analyzes breakout locations of past events, and (iii) compares the reconstructed time series with archival data.

\section{Study site}

The Manival torrent (Isère, French Prealps, $45^{\circ} 17^{\prime} \mathrm{N}$, $5^{\circ} 49^{\prime} \mathrm{E}$ ) is considered one of the largest debris-flow torrents of the Northern French Prealps (Besson, 1996; Fig. 1a). It is located in the Massif de la Chartreuse on the southeastern slopes of the Isère valley, about $10 \mathrm{~km}$ north of Grenoble (Fig. 2a). The catchment has a size of $7.3 \mathrm{~km}^{2}$ and extends from Bec Charvet at $1738 \mathrm{~m}$ a.s.l. to the confluence with the Isère River at $250 \mathrm{~m}$ a.s.l.

Debris flows at Manival are commonly triggered from a large amphitheatre located in an anticline and developed in intensely folded and interbedded limestones and marls (mean thickness: $1000 \mathrm{~m}$ ) of Jurassic age (Gignoux and Moret, 1952). As a result, bedrock is intensely fractured and therefore highly sensitive to weathering and erosion. The upper basin hillslopes are almost devoid of vegetation and have mean slope angles varying between 40 and $50^{\circ}$. Due to lacking local pluviometric data, precipitation has been extrapolated from data of the nearby Saint Martin d'Hères station $\left(45^{\circ} 10^{\prime} \mathrm{N}, 5^{\circ} 46^{\prime} \mathrm{E}, 220 \mathrm{~m}\right.$ a.s.l.; Mathys, 1988; Brochot, 1991; Gruffaz, 1997). Mean annual precipitation is about $1000 \mathrm{~mm}$ in the lower parts of the basin and $1800 \mathrm{~mm}$ at its summit (mean: $1250 \mathrm{~mm}$; Veyrat-Charvillon, 2005). Extreme daily precipitations with decadal recurrence are estimated to $100 \mathrm{~mm}$, with intense rainstorms being most frequent in summer. Debris flows at Manival have generally occurred during late spring and summer.

The Manival fan has a size of $4.3 \mathrm{~km}^{2}$, and a mean slope angle of $8^{\circ}$. The alluvial fan has a radius of $2 \mathrm{~km}$ and displaced the Isère River to the northwestern slopes of the main valley. The fan is largely non forested below $460 \mathrm{~m}$ a.s.l. and occupied by the villages of Saint-Nazaire-les-Eymes, SaintIsmier, and Bernin (Fig. 1a).

Archival data on debris flows at Manival are available from different sources (Lang et al., 2003). Fifty-six damaging events have been recorded since AD 1673. Recently, National Agency for Mountain Terrain Restoration (RTM) has listed 25 debris flow since 1900, but the chronology is likely to be rather incomplete (Brochot et al., 2000; Lang et al., 2003). According to the sources listed above, the last debris flow reaching the bottom of the fan occurred in 1953. Ever since, urban development has increased on the fan. Quantitative data on events is scarce and limited to the recent past; the largest event on record occurred in 1968 and deposited $\sim 60000 \mathrm{~m}^{3}$ of debris on the fan (Veyrat Charvillon, 2005), but RTM only estimated the volume of five debrisflow events in 1968, 1984, 1991, 1998, and 2008.

Between 600 and $850 \mathrm{~m}$ a.s.l., the Manival torrent has formed a 300-m wide and incised valley with a mean slope angle of $11^{\circ}$ (Fig. 2b, c). This reach of the Manival torrent has received considerable attention by RTM since the late 19th century (Veyrat-Charvillon and Memier, 2006): in 1926, two 150 and 230-m long dykes were built on both sides of the active channel (Fig. 2c), leading to an open central 


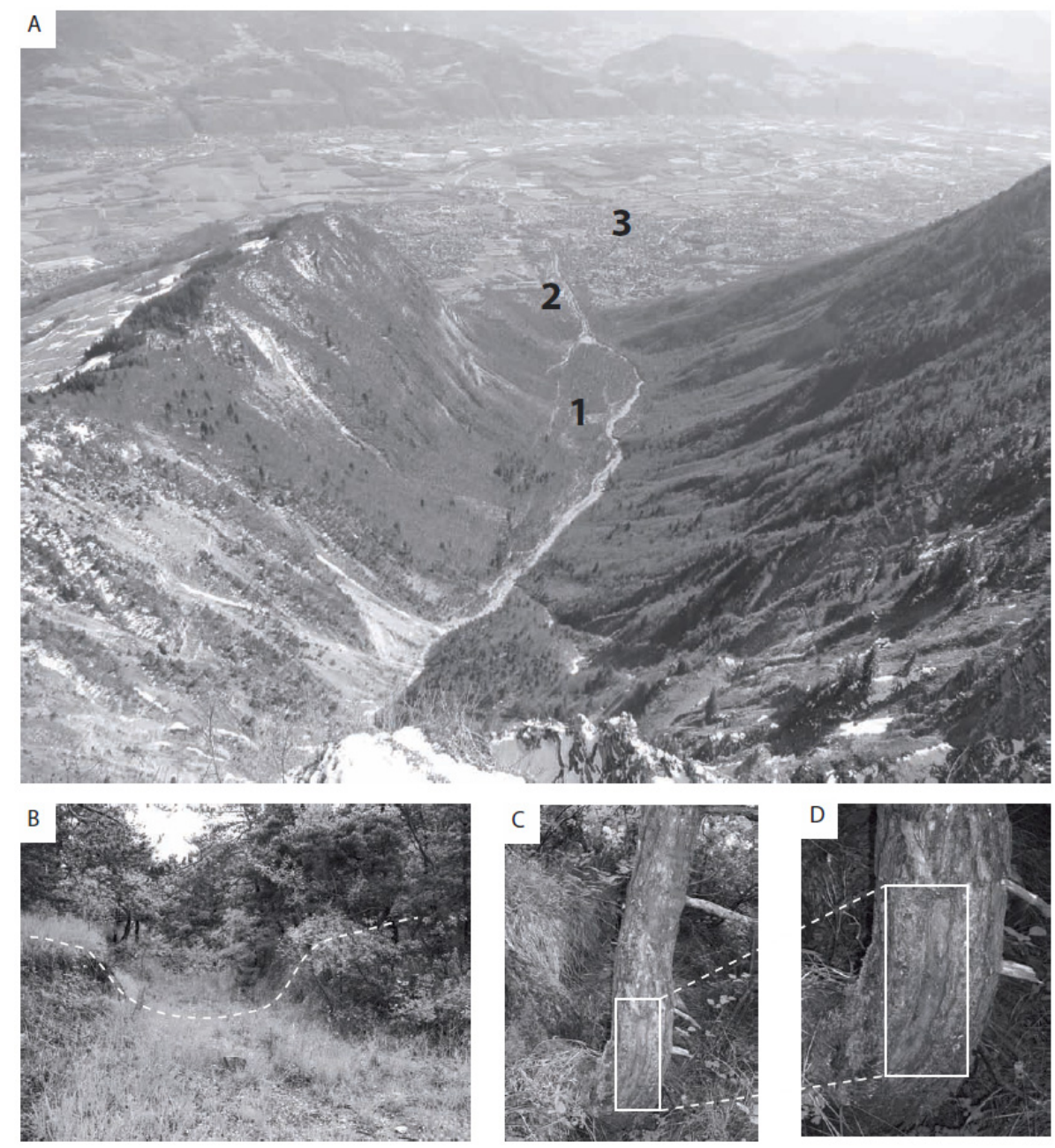

Fig. 1. (A) Overview of the Manival catchment as seen from the upper basin with (1) the study site, (2) debris-flow cone, and (3) the village of Saint-Ismier; (B) View of an abandoned channel with characteristic lateral levees covered with $(\mathbf{C}, \mathbf{D})$ trees affected by past debris-flow activity.

deposition zone. In addition, several check dams have been constructed to control channel scour. Since 1992, a large check dam and a $25000-\mathrm{m}^{3}$ sediment trap prevent debris to move below $550 \mathrm{~m}$ a.s.l. The active channel is located inside the dykes and up to $10 \mathrm{~m}$ below the cone surface covered with an open P. sylvestris forest.

\section{Material and methods}

\subsection{Geomorphic mapping}

Fieldwork started with the mapping (scale: 1/1000) of features associated with past debris-flow activity such as abandoned flow paths and channels, as well as levees and lobes, using airborne LiDAR data. LiDAR data acquisition was performed in spring 2009 by Sintegra (Meylan, France) using a Riegl ${ }^{\circledR}$ LMS-Q560 laser scanner. Flight height was $\sim 2000 \mathrm{~m}$, resulting in a footprint size of $\sim 0.25 \mathrm{~m}$. The point density was 5 points $\mathrm{m}^{-2}$. An Ordinary Kriging interpolation was performed with ArcMAP 9.3 (ESRI Corp.) and a DEM with a $1-\mathrm{m}$ resolution was derived from the LiDAR data. Using the Spatial Analysis Toolbox, two hillshade maps (Fig. 2c) were created from the DEM with a sun elevation angle of $30^{\circ}$ and an azimuth angle of 45 and $315^{\circ}$. These hillshade maps, combined with aerial orthophotos, were used to digitize abandoned channels and geomorphic forms associated with past debris-flow activity. All the features of the LiDAR-derived geomorphic map were then validated during a field survey.

\subsection{Sampling strategy}

Based on the geomorphic map and an outer inspection of the stem surface, 312 increment cores were sampled from 156 P. sylvestris trees. Two cores were sampled from each 

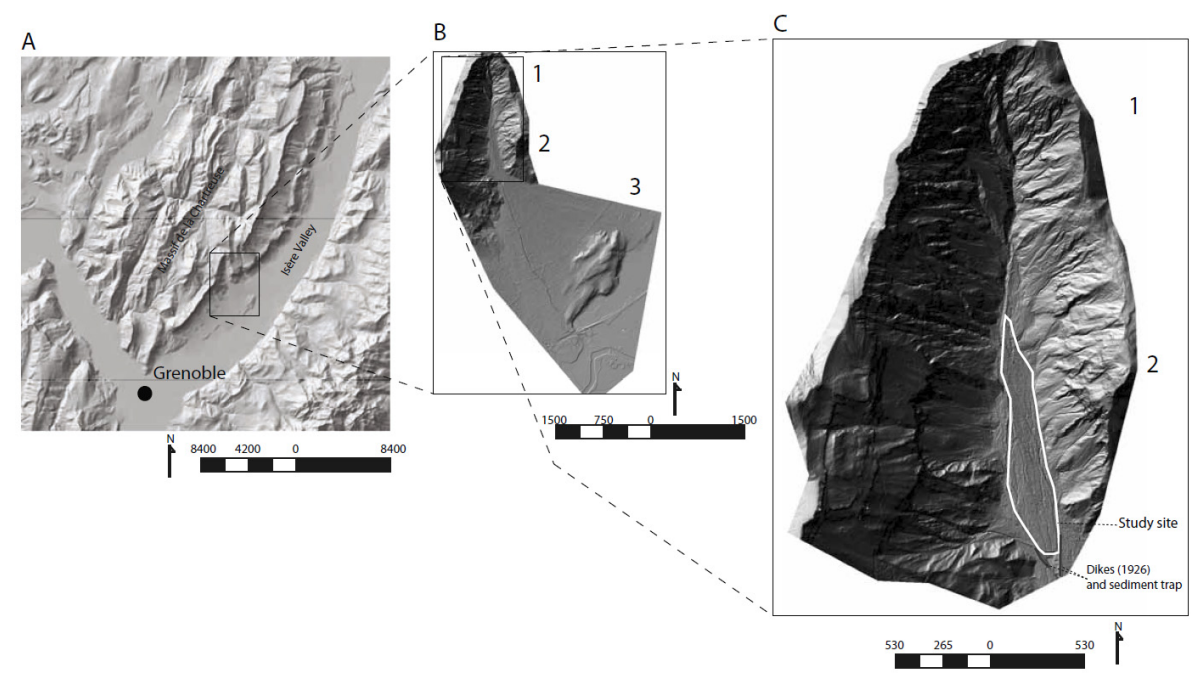

Fig. 2. (A) The Manival torrent is located on the southeastern slopes of the Massif de la Chartreuse, $10 \mathrm{~km}$ northeast of Grenoble. (B) It is composed of three characteristic parts: (1) the upper basin, (2) a large valley with an active flow channel and several abandoned channels, and (3) the debris-flow cone. (C) Detail of the study site.

tree in the flow direction. GPS coordinates with $<1 \mathrm{~m}$ accuracy were recorded for each tree sample using a Trimble GeoExplorer. Sampling height was chosen according to the morphology of the stem: injured or tilted trees were sampled at the height of the disturbance; cores from buried and/or decapitated trees were extracted next to the stem base so as to preserve as much tree-ring information as possible (Bollschweiler et al., 2008); cores from trees showing no visible GD were extracted at an average height of $\sim 130 \mathrm{~cm}$. In addition to the trees sampled inside the channels, fifteen undisturbed $P$. sylvestris trees showing no signs of geomorphic impacts were selected on the cone and used to build a reference chronology. Two cores were extracted per tree, perpendicularly to the slope, at breast height.

\subsection{Tree-ring analysis}

In the laboratory, tree samples were analyzed and data processed following the standard procedures described in Stoffel and Bollschweiler (2009). Single steps of surface analysis included sample mounting on a slotted mount, sample drying, and surface preparation by finely sanding the upper core surface up to grit size 600 . In the laboratory, tree rings were counted and ring widths measured to the nearest $0.01 \mathrm{~mm}$ using a digital LINTAB positioning table connected to a Leica stereomicroscope and TSAPWin Scientific software (Rinntech, 2011).

The reference chronology (Fig. 4) was developed based on the growth curves of the undisturbed trees using ARSTAN software (Cook, 1985). The two measurements of each reference tree were averaged, indexed and detrended using a double detrending procedure (Holmes, 1994) with the purpose to enhance the climate signal in ring width series. First, a negative exponential curve (or linear regression) was fitted to the ring series. In a second step we used a cubic smoothing spline function with a frequency-response cut-off set at two-thirds of the length of each series (Cook and Kairiukstis, 1990). This process created stationary time series for each tree with a mean of 1 and an homogeneous variance. It resulted in a unitless index of radial tree growth. In this way, most of the variability in each ring series assumed to be unrelated to climate such as tree aging and forest stand development was removed.

Increment curves of the disturbed samples were then cross-dated with the reference chronology. The quality of the cross-dating was evaluated using COFECHA (Holmes, 1983 ) as well as the graphical functions of TSAPWin (Rinntech, 2011). The purpose of this procedure was (i) to correct faulty tree-ring series derived from disturbed samples (e.g. false or missing rings) and (ii) to separate climatically driven fluctuations in tree growth from growth disturbances caused by debris-flow activity. As no significant correlation was found between the reference chronology and 6 cores from affected trees $(3.8 \%)$, these cores were not considered for further analysis.

\subsection{Sign of disturbance in the tree-ring record}

Depending on their volume, velocity or energy, debris flows can injure trees by (i)tilting, (ii) breaking or (iii) scarring stems (Fig. 1c, d). Cross-dated growth curves were used to determine the initiation of GD. A reduction in annual ring width over several years was interpreted as damage to the root system, loss of a major limb, or a partial burial of the trunk resulting from debris-flow activity (Stoffel and Bollschweiler, 2008). In this study, growth-ring series had 

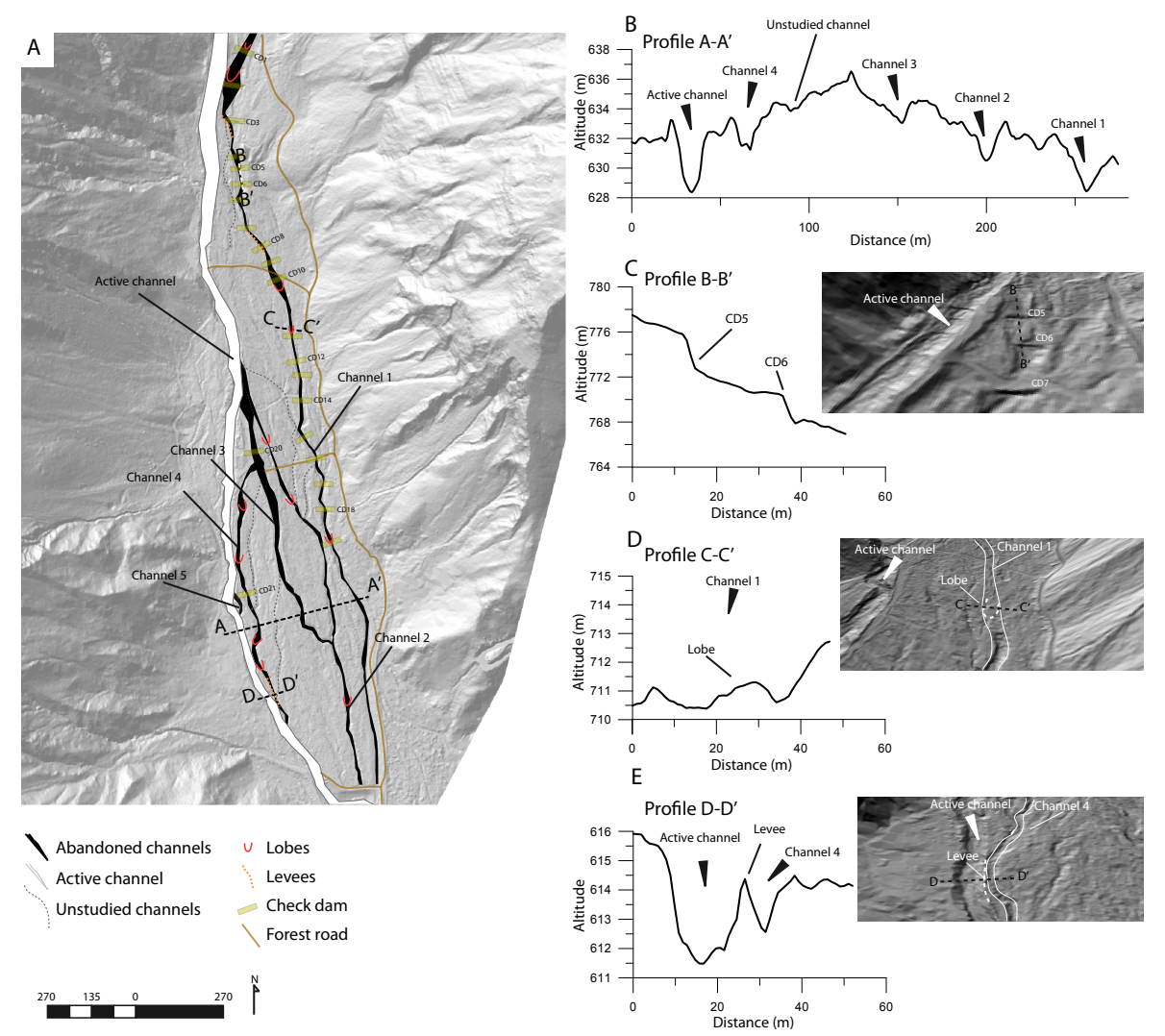

Fig. 3. (A). Abandoned channels identified on the hillshade map computed using the DEM derived from airborne LiDAR data. (B, C, D, E) Profiles of the Manival torrent at four characteristics location. (A) Cross sections of the five studied abandoned channels. (B) The check dams constructed in the 1950s and 1960s. (C) Section of a depositional lobe. (D) Section of the active channel.

to exhibit (i) a marked reduction in annual ring width for at least three consecutive years, such that the (ii) width of the first narrow ring was $50 \%$ or less of the width of the annual ring of the previous year.

In the case of tilted stems, both the appearance of the cells and growth curve data were analyzed (e.g., Braam et al., 1987). The onset of compression wood is interpreted as a response to stem tilting induced by a unilateral debris-flow pressure (Fantucci and Sorriso-Valvo, 1999). At the level of tree rings, the tilting of conifer trunks will result in asymmetric tree-ring growth, i.e. in the formation of wide annual rings with smaller, reddish-yellow colored cells with thicker cell walls (so-called compression wood; Timell, 1986) on the tilted side and narrow (or even discontinuous) annual rings on the opposite side of the tree (Panshin and de Zeeuw, 1970; Carrara and O'Neill, 2003).

Finally, cores were visually inspected so as to identify further signs of past debris-flow activity. The formation of callus tissue was interpreted as a reaction to the corrasion of tree stems by the flow that causes cambium damage and scars (Hupp, 1984).

\subsection{Reconstructing frequency and assessing spatial patterns of past events}

After the dating of GD on the samples, the position of all trees with GD in the same year was marked on the geomorphic map. This representation of trees affected during individual events allowed the identification and interpretation of spatial patterns of past events in currently abandoned channels. We required that a minimum of five trees exhibits a response for an event to be dated. Preferential breakout locations, as well as the travel distance of the reconstructed debris-flow events, were assessed by the distribution of disturbed trees in a specific event year.

\section{Results}

\subsection{Geomorphic map}

Geomorphic mapping allowed identification of features related to past debris-flow activity on the depositional cone of the Manival torrent. The features and deposits inventoried in the study area covering approximately 15 ha are illustrated in Fig. 3a and include five well-developed abandoned 


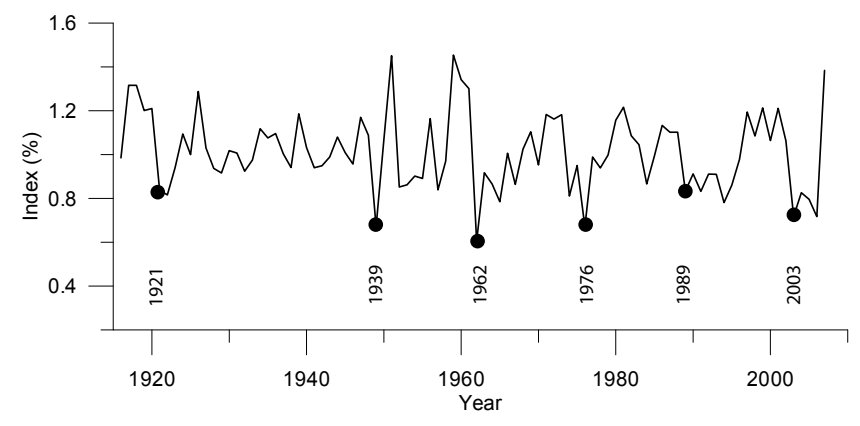

Fig. 4. Tree-ring chronology of Pinus sylvestris L. for the Manival torrent dating back to 1918 . Individual series are detrended with (i) a negative exponential curve or a linear regression and (ii) by a cubic smoothing spline function.

channels (Fig. 3b, c, d, e). The tracks of these abandoned channels are still clearly visible on the LiDAR derived hillshade maps, although their banks have partially collapsed since the last debris-flow activity and their beds are now recovered by fallen debris and vegetation (Fig. 1b). The length of channels varies from 60 (channel 5) to $1300 \mathrm{~m}$ (channel 1) with depths of 1 to $3 \mathrm{~m}$ and widths comprised between 5 and $20 \mathrm{~m}$ (Fig. 3b, c, d, e). All channels are bordered with characteristic depositional lobes and lateral levees (Fig. 3d, e).

\subsection{Age structure of the stand and growth disturbances}

A total of 156 trees was cored at Manival, $36(23 \%)$ in channel $1,79(51 \%)$ in channel $2,13(8 \%)$ in channel 3 , $21(14 \%)$ in channel 4, and $7(4 \%)$ in channel 5. Visual cross-dating was carried out by means of the skeleton plot method and primarily based on the narrow rings of 1921, 1939, 1962, 1976, 1989, and 2003 (Fig. 4). The average age at sampling height was $62 \pm 27 \mathrm{yr}$. While the oldest tree selected for analysis attained sampling height in AD 1875, the youngest sample only reached breast height in 1989. The spatial distribution of tree ages within the stand is heterogeneous (Fig. 5), with older trees mainly being located in the upper part of channel 4 (average age $=95 \pm 14 \mathrm{yr}$ ) and youngest trees growing in the lower parts of channel 1 (average age $=29 \pm 6 \mathrm{yr}$ ). The stand appears relatively homogeneous (average age $=60 \pm 11 \mathrm{yr}$ ) in the lower part of channel 2.

Amongst the sampled trees, $15(9 \%)$ showed at least one visible scar, $41(27 \%)$ were tilted, and $100(64 \%)$ exhibited no external defects. The 312 samples permitted identification of $375 \mathrm{GD}$ in the form of compression wood after tilting (196 cases, 53\%), callus tissue $(15 ; 4 \%)$, and abrupt growth releases or growth suppressions (164, 43\%; Fig. 6). The oldest GD in the tree-ring series was dated to 1878 and GD became more frequent after 1930. In total, GD allowed reconstruction of 13 debris-flow events between 1931 and 2008: 1931, 1936, 1946, 1953 1956, 1967, 1972, 1974, 1975, 1981, 1989,

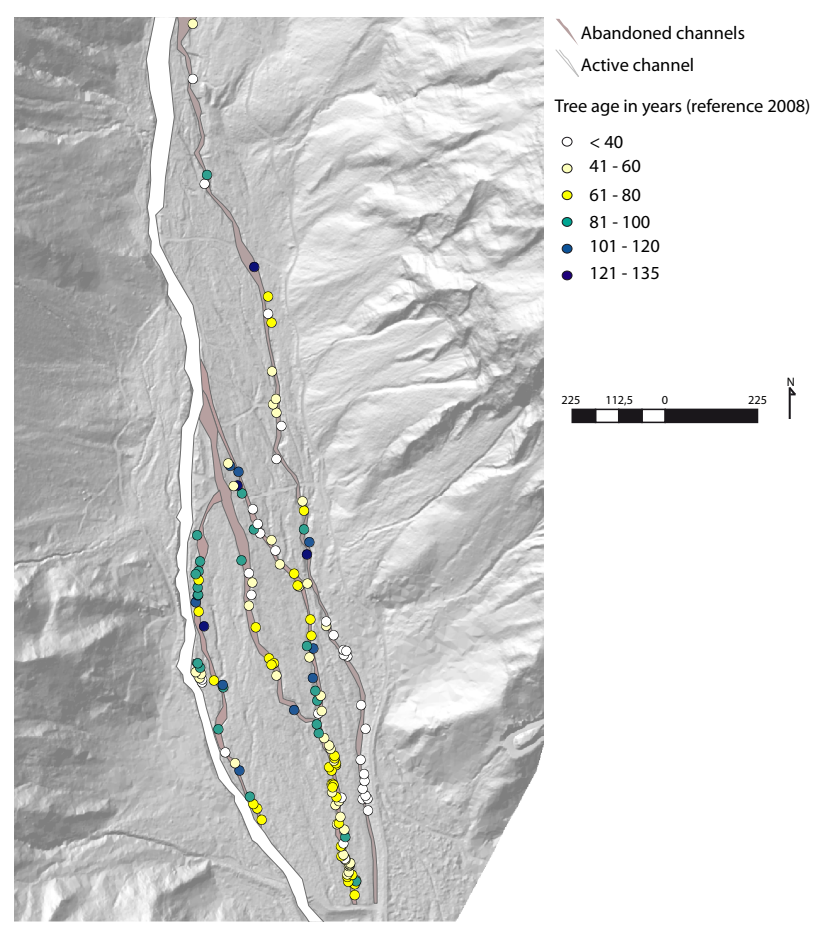

Fig. 5. Age structure of the forest stand at the study site.

1990, 2000 (Fig. 6). The years 1974 (24\%), 1990 (40\%), and $2000(24 \%)$ are those exhibiting the largest number of trees responding to debris-flow disturbance.

\subsection{Spatial distribution of trees affected by debris flow}

Maps illustrating the spatial distribution of characteristic Manival debris flows are provided in Fig. 7; they point to the presence of four patterns of debris-flow routing with respect to the overflowing point. In flow pattern A, illustrated with a debris flow dated to 1975 (Fig. 7), surges leave the currently active Manival channel at the uppermost diffluence at 820 m a.s.l. The 1975 debris flow disturbed all trees in and next to channel 1 and was stopped at $\sim 690 \mathrm{~m}$ a.s.l. when it reached check-dam CD14. The debris flows of 1967, 1972, 1974, and 1981 can be summarized with flow pattern B. Here, events apparently avulsed between the active channel and channels 2, 3, and 4 at $\sim 700 \mathrm{~m}$ a.s.l.; and flowed through channels 2 in 1967, 3 in 1974, and 4 in 1972 and 1981. The different flows converged again with the active channel at $\sim 600 \mathrm{~m}$ a.s.l. in 1972 and 1981 to reach the check dam at $550 \mathrm{~m}$ a.s.l. Flow pattern $\mathrm{C}$ is illustrated with the debris flow of 1989 , when a spatially limited overflow event left the active channel at $\sim 640$ m a.s.l. to disturb a limited number of trees located in channel 5. Finally, flow pattern D is represented by debris flows in 1953, 1956, 1990, and 2000. This type of event shows two sets of possible breakout locations at 820 and $700 \mathrm{~m}$ a.s.l. $(1953,1990,2000)$ and 


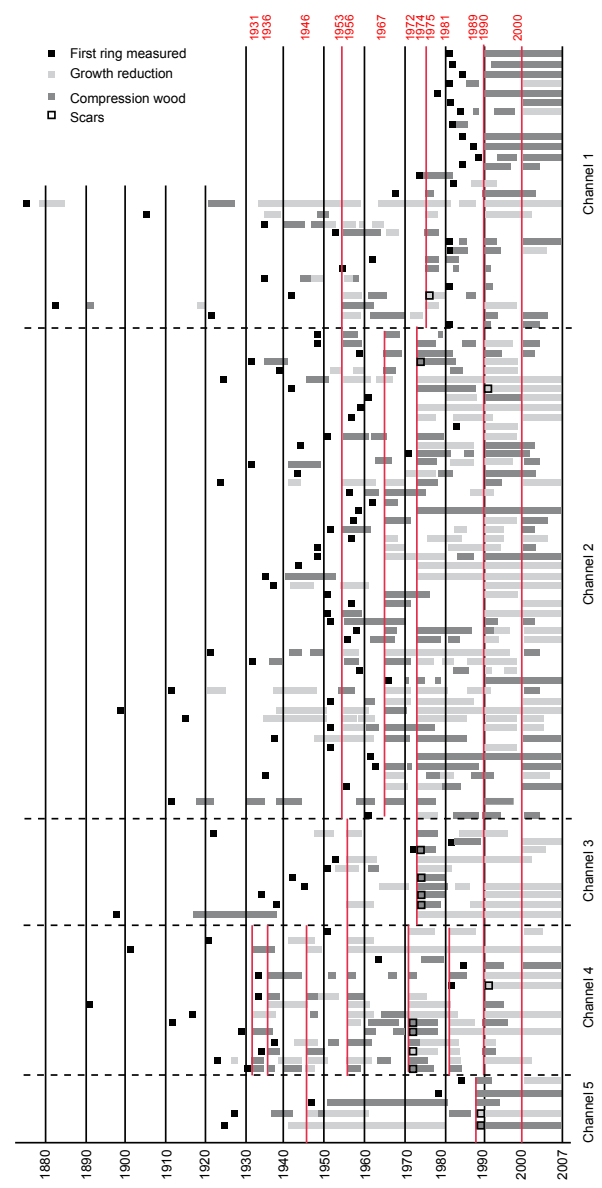

Fig. 6. Skeleton plot showing event responses from tree samples collected in or next to the five abandoned channels of the Manival torrent.

at 700 and $680 \mathrm{~m}$ a.s.1 (1956), respectively. The 1953 debris flow preferentially affected trees located in channels 1 and 2 and was deposited halfway down the channel, at the confluence between channels 2 and 3 (620 m a.s.l.). In 1956, surges traveled the entire length of channel 4 and stopped at $\sim 620$ m a.s.l., mainly causing damage to trees located in the upper part of channel. The massive debris flows of 1990 and 2000 left damages to vegetation in all channels.

\section{Discussion}

In this study, a coupling of detailed geomorphic mapping with dendrogeomorphic analysis has been used to reconstruct the frequency and spatial extent of debris-flow events in the Manival torrent over the last 80 years. Analysis yielded extensive data on 13 events between 1931 and 2008 and allowed reconstruction of past debris-flow activity in five channels that are currently abandoned. In addition, the large amount of tree-ring data combined with the results from the geomorphic mapping enabled distinction of four different patterns of spatial activity of former debris flows and identification of preferential breakout locations of debris-flow surges.

The dendrogeomorphic reconstruction of debris-flow activity at Manival was limited by the relatively young age of trees. Although trees with more than 130 increment rings were identified, the average age of $P$. sylvestris was only $62 \mathrm{yr}$ at the study site. In the lower part of channel 1, most trees were even younger and averaged only 29 yr. Furthermore, we need to stress that this study exclusively focused on debris-flows that actually left the active channel and reactivated abandoned channels on the cone surface. The more frequent but smaller debris flows, such as those registered in February 1963 or July 1993 (Veyrat-Charvillon, 2005), do not appear in our reconstruction, as they were contained within the active channel and did not cause any damage to the vegetation growing on the cone. Conversely, it is also known that debris flows may partly or entirely eliminate forest stands (Arbellay et al., 2010), thus masking witnesses of former events. Finally, we need to bear in mind that we exclusively sampled trees along or within abandoned channels and thus may have overlooked older events in areas where signs of former channel processes may have been masked by more recent deposits (Sorg et al., 2010). As a result of the above considerations, the number of reconstructed events has to be seen as a minimum frequency, despite the fact that most (if not all) breakout events with channel reactivation have been captured since the 1930s as a result of the large replication of trees showing GD in individual years.

In this study, the onset of compression wood after tilting and abrupt changes in growth (releases or suppression) were by far the wound type most frequently observed (53\% and $43 \%$, respectively); injuries caused by the abrasive action of debris-flow sediment were, in contrast, rare and only accounted for $4 \%$ of all reconstructed GD. This scarcity of injuries as compared to other signs of past activity may reflect the sampling strategy. In this study, increment cores were used rather than cross-sections, since the forest at Manival has a protective function and trees could not therefore be felled for analysis. As a result of the thick and rough bark of $P$. sylvestris, external signs of injuries are very efficiently and rapidly blurred on the stem surface, as it grows abundantly and sporadically scales off its outermost bark layers (Stoffel and Perret, 2006). Furthermore, P. sylvestris abundantly produces vertical resin ducts in its phloem and xylem, but does not, at the same time, produce tangential rows of traumatic resin ducts (TRD) as a reaction to mechanical wounding (Stoffel, 2008). As a result, in contrast to other conifer species, TRD cannot be used to indirectly date overgrown abrasion scars.

On a temporal scale, our reconstruction considerably complemented archival records of debris-flows at Manival (Fig. 8). Only four of the 13 events reconstructed in this study were previously known from archival records, namely the debris flows of 1953, 1975, 1990, and 2000. 

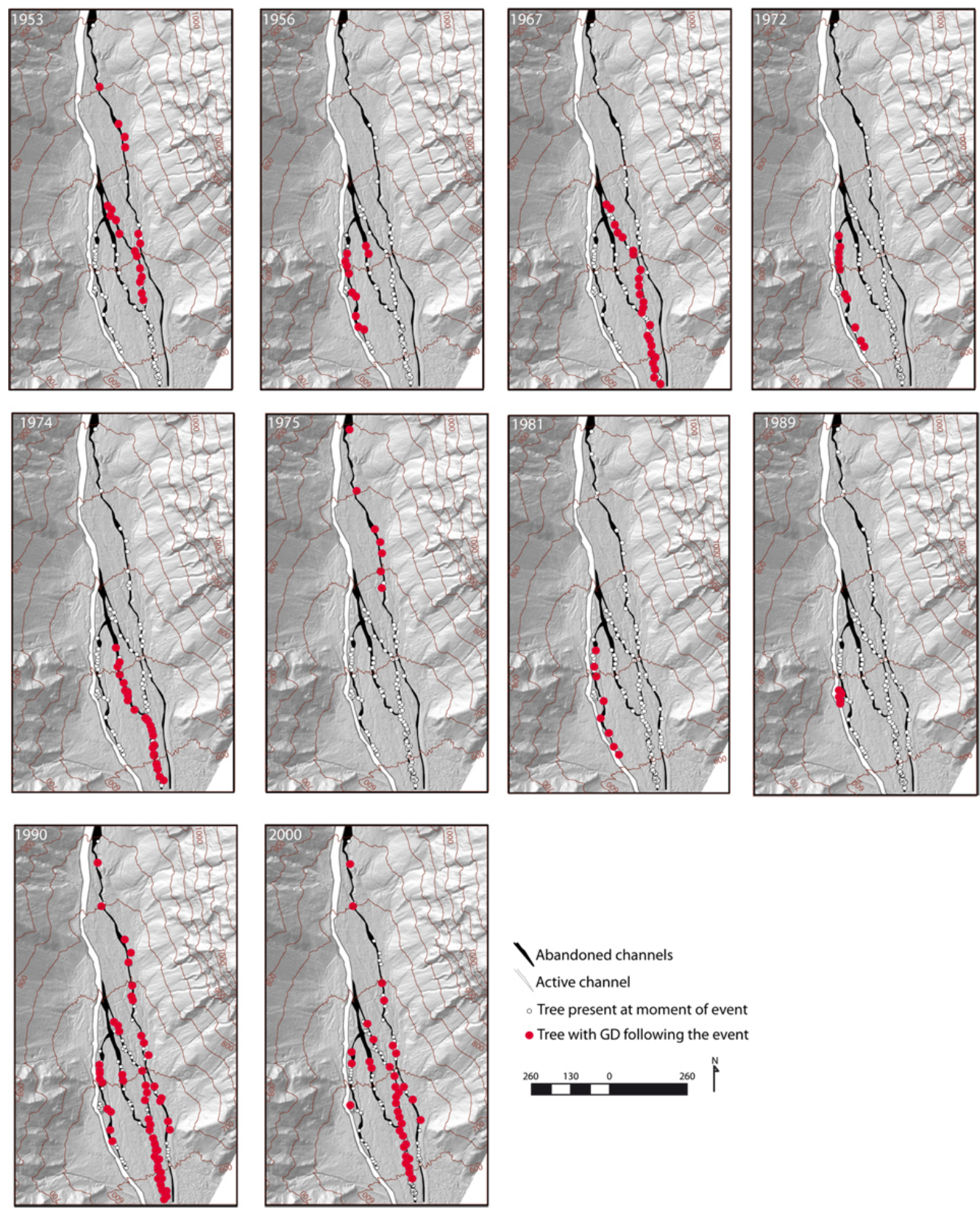

Fig. 7. Location of trees showing growth disturbances (GD) during reconstructed debris-flow events. Maps show all living trees as well as those trees showing an event-response to debris-flow activity in a particular year.

More importantly, the events reconstructed in 1931, 1936, and 1946 filled a considerable gap in historical archives between 1920 and 1948, which was probably related to insufficient monitoring by the RTM (Brochot et al., 2000). In combination with the tree-ring record, the database of historic Manival debris flows now contains a total of 33 events spanning more than $100 \mathrm{yr}$. Although we are able to identify three periods with increased debris-flow activity in the record (i.e. 1900s, 1950s, and 1990s), we do not consider our database long and complete enough to postulate for an unequivocal evidence of changes and trends in debris-flow frequency during the 20th century as a result of climate change, as put forward by other studies which were based on much larger and longer time series (e.g. Stoffel and Beniston, 2006; Jomelli et al., 2009).

On a spatial scale, this study has contributed to the documentation and understanding of avulsion events, the localization of the most active breakout locations and to the spread and reach of debris flows on the cone of the Manival torrent. Interestingly, the four events known from archives 


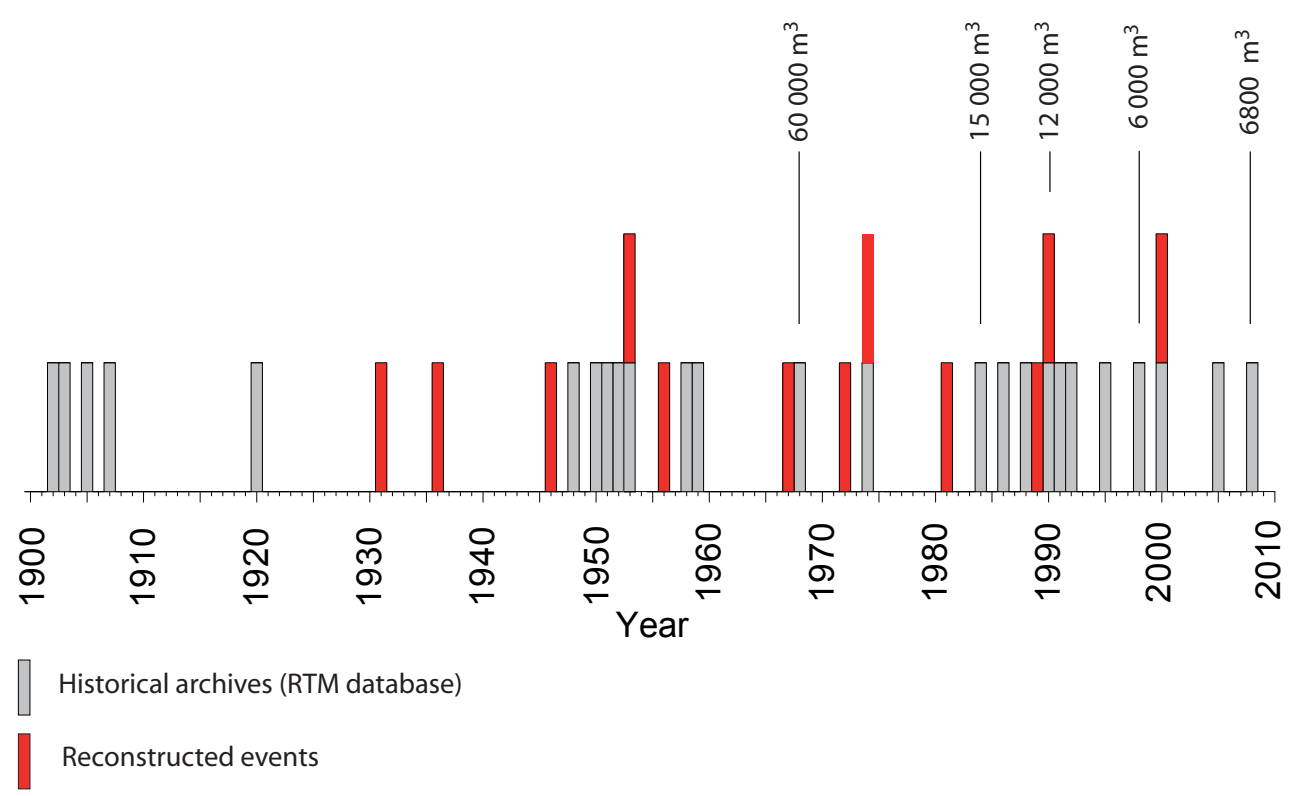

Fig. 8. Comparison of debris-flow frequency as documented from historical archives and with the reconstructed time series obtained with dendrogeomorphic methods at Manival.

and confirmed with dendrogeomorphology (i.e. 1953, 1975, 1990, and 2000) all correspond to flow patterns A and D. They disturbed trees located in or next to channel 1 after having left the current main channel at $\sim 820 \mathrm{~m}$ a.s.l. The good concordance between these events and the databases probably reflects the more accurate monitoring of this sector of the cone by the RTM, as channel 1 - also called "Le Petit Manival" (little Manival) - directly threatens the village of Bernin, with destructive events being reported at the turn of the 19th and 20th centuries (1889, 1894, 1902, 1903, 1905, 1907, 1920).

Reconstructed events with outbreaks from the main debrisflow channel were compared with volumes of events estimated by RTM (Fig. 8). The known debris flow of $1990\left(12000 \mathrm{~m}^{3}\right)$ was confirmed by tree-ring analysis, as it overflowed the main channel at $820 \mathrm{~m}$ a.s.l. and disturbed trees located in all abandoned channels (Fig. 7). Conversely, it was not possible to reconstruct the events that occurred in 1968, 1984, 1998, and 2008 with dendrogeomorphology. In 1968, the debris-flow surge noted in the RTM database $\left(60000 \mathrm{~m}^{3}\right)$ stopped at $\sim 850 \mathrm{~m}$ a.s.l. upstream from the study site. Based on personal observations, the event of $2008\left(6800 \mathrm{~m}^{3}\right)$ was restricted to the active channel. Similarly, we hypothesize that the events of $1984\left(15000 \mathrm{~m}^{3}\right)$ and $1998\left(6000 \mathrm{~m}^{3}\right)$ did not overflow the active to affect the abandoned channels. A definition of volume threshold above which debris flows will reactivate channels on the cone is therefore not possible based on the data available. Even more, it seems very likely that the maximum capacity of the main channel varies with time and - depending on channel geometry - the flood management strategies and the flow dynamics and characteristics of events in those areas where avulsion and reactivation of abandoned channels are possible.

\section{Conclusions}

In this study, the use of aerial LiDAR data permitted geomorphic mapping of five well-developed abandoned channels of the Manival torrent. Tree-ring analysis coupled with geomorphic mapping allowed reconstruction of 13 events covering the last 80 years. On a temporal scale, the dendrogeomorphic study of abandoned channels has proved to be a powerful tool in substantially adding to the historic record centered on the active channel. The composite chronology revealed that the frequency of debris-flow events had not been significantly modified since the beginning of the $20^{t h}$ century as previously suggested by (incomplete) historical archives. Although the relatively young age of sampled trees limited the reconstruction, the $P$. sylvestris trees selected for analysis provided very detailed insights into recent debris-flow activity and routing at the study site. Analysis of the spatial distribution of disturbed trees contributed to the identification of four patterns of debris-flow routing in abandoned channels. Three preferential breakout locations of events could be determined and the travel distance of debris-flow surges assessed. Finally, despite the accurate monitoring of the Manival torrent, our study demonstrates the reliability of dendrogeomorphic approaches to substantially complement historical archives. 
Acknowledgements. This research has been supported by the PARAmount project, "ImProved Accessibility, Reliability and security of Alpine transport infrastructure related to mountainous hazards in a changing climate", funded by the Alpine Space Programme, European Territorial Cooperation, 2007-2013. It has also been supported by the DENDROGLISS program, funded by the MAIF foundation and by the EU-FP7 project ACQWA (project no. GOCE-20290) and PGRN project. The authors wish to thank ONF-RTM38 colleagues for sampling permission, archival data, and field access.

Edited by: R. Lasaponara

Reviewed by: A. Bartosik and another anonymous referee

\section{References}

Alestalo, J.: Dendrochronological interpretation of geomorphic processes, Fennia, 105, 1-140, 1971.

Arbellay, E., Stoffel, M., and Bollschweiler, M.: Dendrogeomorphic reconstruction of past debris-flow activity using injured broad-leaved trees, Earth Surf. Proc. Land, 35, 399-406, 2010.

Barriendos, M., Coeur, D., Lang, M., Llasat, M. C., Naulet, R., Lemaitre, F., and Barrera, A.: Stationarity analysis of historical flood series in France and Spain (14th-20th centuries), Nat. Hazards Earth Syst. Sci., 3, 583-592, doi:10.5194/nhess-3-5832003, 2003.

Besson, L.: Les risques naturels en Montagne, Editions ArtesPubialp, Grenoble, 438 pp., 1996.

Bollschweiler, M. and Stoffel, M.: Tree rings and debris flows trends and challenges, Prog. Phys. Geog., 34, 625-645, 2010a.

Bollschweiler, M. and Stoffel, M.: Variations in debris-flow occurrence in an Alpine catchment - A reconstruction based on tree rings, Global Planet. Change, 73, 186-192, 2010 b.

Bollschweiler, M., Stoffel, M., and Schneuwly, M.: Dynamics in debris-flow activity on a forested cone - a case study using different dendroecological approaches, Catena, 72, 67-78, 2008.

Braam, R. R., Weiss, E. E. J., and Burrough, P. A.: Spatial and temporal analysis of mass movement using dendrochronology, Catena, 6, 573-584, 1987a.

Brochot, S.: Torrrent du Manival, Etude préalable à l'aménagement (rapport), Cemagref/RTM/SITSE, Grenoble, 26 pp., 1991.

Brochot, S., Coeur D., Lang, M., and Naulet, R. : HistorisqueIsère et torrents affluents. Utilisation de l'information historique pour une meilleure définition du risqué d'inondation, Cemagref/Achtys, Lyon, Grenoble, 2000.

Carrara, P. E. and O’Neill, J. M.: Tree-ring dated landslide movements and their relationship to seismic events in southwestern Montana, Quaternary Res., 59, 25-35, 2003.

Cœur, D. and Lang, M.: Use of documentary sources on past flood events for flood risk management and land planning, Compte Rendus Geosciences, 340, 644-650, 2008.

Cook, E. R.: A time series analysis approach to tree-ring standardization, PhD Dissertation, University of Arizona, Tucson, AZ, USA, 1985.

Cook, E. R. and Kairiukstis, L. A.: Methods of dendrochronology - applications in the environmental sciences, Kluwer, London, UK, 1990.
Fantucci, R. and Sorriso-Valvo, M.: Dendrogeomorphological analysis of a slope near lago, Calabria (Italy), Geomorphology, 30, 165-174, 1999.

Gignoux, M. and Moret, L.: Géologie Dauphinoise, Masson, Paris, 391 pp., 1952.

Gruffaz, F.: Torrent du Manival, Isère, Etude de bassin et de la plage de depots torrentiels. Rapport RTM / ONF, Grenoble, 66 pp., 1997.

Holmes, R.: Dendrochronology Program Library User's Manual, Laboratory of Tree-Ring Research University of Arizona, Tucson, 1994.

Holmes, R.: Computer-assisted quality control in tree-ring dating and measurement, Tree-ring Bulletin, 44, 69-75, 1983.

Hupp, C. R.: Geo-botanical evidence of late Quaternary mass wasting in block field areas of Virginia, Earth Surf. Proc. Land, 8, 439-450, 1983, 1984.

Ibsen, M. L. and Brunsden, D.: The nature, use and problems of historical archives for the temporal occurrence of landslides, with specific reference to the south coast of Britain, Ventnor, Isle of Wight, Geomorphology, 15, 241-258, 1996.

Jakob, M.: Debris flow hazard analysis, in: Debris flow hazards and related phenomena, edited by: Jakob, M. and Hungr, O., Praxis Publishing, Chichester, UK, 411-438, 2005.

Jakob, M. and Bovis, M. J.: Morphometrical and geotechnical controls of debris flow activity, southern Coast Mountains, British Columbia, Canada, Z. Geomorphol. Supp., 104, 13-26, 1996.

Jomelli, V., Brunstein, D., Déqué, M., Vrac, M., and Grancher, D.: Impacts of future climatic change (2000-2100) on the occurrence of debris flows: A case study in the Massif des Ecrins (French Alps), Climatic Change, 97, 171-191, 2009.

Lang, M., Coeur D., Brochot S., and Naulet R.: Information historique et ingénierie des risques naturel, L'Isère et le torrent du Manival, Cemagref editions, 182 pp., 2003.

Mathys, N.: Les torrents du Saint-Eynard. Rapport Cemagref, Grenoble, France, 1988.

Mayer, B., Stoffel, M., Bollschweiler, M., Hübl, J., and RudolfMiklau, F.: Frequency and spread of debris floods on fans: a dendrogeomorphic case study from a dolomite catchment in the Austrian Alps, Geomorphology, 118, 199-206, 2010.

Panshin, A. J. and de Zeeuw, C.: Textbook of Wood Technology, 1, 3rd edn., 705 pp., McGraw-Hill, New York, USA, 1970.

Rinntech: http://www.rinntech.com/content/blogcategory/2/28/ lang,english/, last access: 1 July 2009, 2011.

Shroder, J., Marston, R. A., and Stoffel, M.: Treatise on Geomorphology, Vol.7, Elsevier B. V, Amsterdam, Ther Netherlands, 460 pp., 2012.

Sorg, A., Bugmann, H., Bollschweiler, M., and Stoffel M.: Debrisflow activity along a torrent in the Swiss Alps: Minimum frequency of events and implications for forest dynamics, Dendrochronologia, 28, 215-223, 2010, doi:10.1016/j.dendro.2009.11.002, 2010.

Strunk, H.: Dating of geomorphological processes using dendrogeomorphological methods, Catena, 31(1-2), 137-151, 1997.

Stoffel, M.: Magnitude-frequency relationships of debris flows - a case study based on field surveys and tree ring records, Geomorphology, 116, 67-76, 2010.

Stoffel, M.: Dating past geomorphic processes with tangential rows of traumatic resin ducts, Dendrochronologia, 26, 53-60, 2008.

Stoffel, M. and Beniston, M.: On the incidence of debris flows from 
the early Little Ice Age to a future greenhouse climate: a case study from the Swiss Alps, Geophys. Res. Lett., 33, L16404, doi:10.1029/2006GL026805, 2006.

Stoffel, M. and Bollschweiler, M.: Tree-ring analysis in natural hazards research - an overview, Nat. Hazards Earth Syst. Sci., 8, 187-202, doi:10.5194/nhess-8-187-2008, 2008.

Stoffel, M. and Bollschweiler, M.: Tree-ring reconstruction of past debris flows based on a small number of samples - possibilities and limitations, Landslides, 6, 225-230, 2009.

Stoffel, M. and Perret, S.: Reconstructing past rockfall activity with tree rings: some methodological considerations, Dendrochronologia, 24(1), 1-15, 2006.

Stoffel, M., Lièvre, I., Conus, D., Grichting, M., Raetzo, H., Gartner, H. W., and Monbaron, M.: 400 years of debris flow activity and triggering weather conditions: Ritigraben, Valais, Switzerland, Arct. Antarct. Alp. Res., 37(3), 387-395, 2005.

Stoffel, M., Bollschweiler, M., Leutwiler, A., and Aeby, P.: Treering reconstruction of debris-flow events leading to overbank sedimentation on the Illgraben cone (Valais Alps, Switzerland), The Open Geology Journal, 2, 36-47, 2008.

Stoffel, M., Bollschweiler, M., Butler D. R., and Luckman B. H.: Tree rings and natural hazards: A state-of-the art, Springer, Dordrecht, Berlin, London, UK, New York, USA, 505 pp., 2010.

Stoffel, M., Bollschweiler M., and Beniston M.: Rainfall characteristics for periglacial debris flows in the Swiss Alps: past incidences - potential future evolutions, Climatic Change, 105, 263$280,2011$.
Szymczak, S., Bollschweiler, M., Stoffel, M., and Dikau, R.: Debris-flow activity and snow avalanches in a steep watershed of the Valais Alps (Switzerland): dendrogeomorphic event reconstruction and identification of triggers, Geomorphology, 116, 107-114, 2010.

Timell, T. E.: Compression wood in gymnosperms, 2150 pp., Springer, Berlin, Germany, 1986.

Tropeano, D. and Turconi, L.: Using historical documents for landslide, debris flow and stream flood prevention, Applications in Northern Italy, Nat. Hazards, 31, 669-673, 2004.

Veyrat-Charvillon, S.: Elaboration d'une méthode de prédiction $\mathrm{du}$ volume maximal d'une lave torrentielle (PREVENT), Géomorphologie torrentielle, Topographie de terrain et Stéréophotogrammétrie sur photographies aériennes d'archives. Torrents du Manival, du Merdarêt et des Arches (Alpes-duNord, Isère, France), Thèse de Doctorat (PhD), Université Blaise Pascal, Clermont-Ferrand, 354 pp., 2005.

Veyrat-Charvillon, S. and Memier, M.: Stereophotogrammetry of archive data and topographic approaches to debris-flow torrent measurements: calculation of channelsediment states and a partial sediment budget for Manival torrent (Isère, France), Earth Surf. Proc. Land, 31, 201-219, 2006.

Wieczorek, G. F. and Snyder, J. B.: Monitoring slope movements, in Young R., and Norby L., Geological monitoring: Boulder, Colorado, Geol. Soc. Am. Bull., 245-271, 2009. 